\section{YEARBOOK of ANTITRUST and REGULATORY STUDIES www.yars.wz.uw.edu.pl}

Peer-reviewed scientific periodical, focusing on legal and economic issues of antitrust and regulation. Creative Commons Attribution-No Derivative Works 3.0 Poland License.

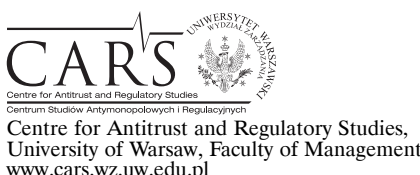

www.cars.wZ.uw.edu.pl

\title{
Antitrust Damages Actions in Ukraine: Current Situation and Perspectives
}

\author{
by
}

Anzhelika Gerasymenko* and Nataliia Mazaraki**

\section{CONTENTS}
I. Introduction
II. Legal rules on private enforcement of competition law in Ukraine
III. Quantifying harm from antitrust infringements in Ukraine
IV. New sources of damages caused by market power
V. Conclusion

\begin{abstract}
The article gives an overview of Ukrainian legislation and experiences concerning antitrust damages actions. The analysis has led to a number of conclusions: private claims are rare in Ukraine due to difficulties in obtaining evidence, high legal costs, and lacking confidence in the Ukrainian court system. The paper gives examples of Ukrainian private antitrust enforcement practice and provides a statistical analysis of the dynamics of 'compensated' damages caused by antitrust infringements in Ukraine. The value of 'compensated' damages is compared to the value of the economic effect of stopping antitrust infringements, as well as to the value of the overall welfare loss deriving from market power in the national economy. Finally, some new sources of damages caused by market power are discussed considering the development perspectives of this branch of antitrust activity.
\end{abstract}

* Associate Professor at the Chair of Economics and Competition Policy of Kyiv National University of Trade and Economics (Ukraine); email: geranzhel@gmail.com. Sections III and IV were written by Anzhelika Gerasymenko whilst Sections I and V are common parts.

** Associate Professor at the Chair of Commercial Law of Kyiv National University of Trade and Economics (Ukraine); email: n.a.mazaraki@gmail.com. Section II was written by Nataliia Mazaraki whilst Sections I and V are common parts. 


\section{Résumé}

Cet article donne un aperçu global de la législation et de l'expérience ukrainienne concernant l'application privée du droit de la concurrence. L'analyse conduit à plusieurs conclusions : les actions en dommages sont rares en Ukraine en raison de difficultés avec l'obtention des preuves, en raison des frais juridiques élevés, et à cause de manque de confiance dans le système judiciaire ukrainien. Cet article donne des exemples de l'application privée du droit de la concurrence en Ukraine et fournit une analyse statistique des préjudices indemnisés causés par les violations du droit de la concurrence. La valeur des préjudices indemnisés est comparée à la valeur de l'effet économique de la cessation des pratiques anticoncurrentielles, ainsi qu'à la valeur d'une perte globale de bien-être pour la société. Enfin, certains nouveaux sources de préjudices causés par un pouvoir de marché sont examinées, en tenant compte des perspectives de développement futur de cette branche du droit de la concurrence.

Key words: antitrust damages actions; private antitrust enforcement; harm from antitrust infringement; non-infringement scenario; economic effect of cease of antitrust infringements; welfare loss from market power.

JEL: K23; K42.

\section{Introduction}

Article 42 of the Constitution of Ukraine provides that 'the State shall ensure the protection of competition in the pursuit of entrepreneurial activity' and bans 'abuse of a monopolistic position in the market, the unlawful restriction of competition, and unfair competition'. It also states that 'the types and limits of monopolies shall be determined by law' and provides that 'the State protects the rights of the consumers'. At the same time, Article 3(1) of the Law on the Protection of Economic Competition (hereafter, LPEC) clarifies that Ukrainian competition law is based on the norms established in the Constitution and consists of: the LPEC, the Law on the Antimonopoly Committee of Ukraine (1993), and the Law on Protection against Unfair Competition (1996), as well as other normative and legislative acts adopted in accordance with these laws. Among other things, they contain provisions that regulate the sphere of damages actions.

Many experts assume that Ukrainian competition law is opaque and often arbitrary, that changes are needed to bring clarity and certainty to the regulatory environment. Some amendments are expected due to Ukraine's commitments to harmonise its laws with European legislation deriving from the Ukraine-EU 
Association Agreement. These changes may lead to growth in the role of private antitrust enforcement which remains a very rare phenomenon next to the central role played still by public enforcement.

To make these changes effective, it is necessary to know what the actual state of damages actions in Ukraine is. It is also essential to understand the practice of damages compensation, which is sometimes more influential for the development of this enforcement sphere than the laws or other official papers on which it is based. This paper provides both the legal and the economic perspective on this issue. In its second section, it gives an overview of the deficiencies of current Ukrainian civil procedural law, which prevent the development of private antitrust enforcement in the country. It also proposes ways to amend existing legislation. The third section of this paper sets out the actual approaches used to quantifying harm caused by antitrust breaches in Ukraine - they are illustrated by specific national antitrust cases. Those cases are not private actions, nevertheless they describe the existing mechanisms of calculating harm by the AMCU, and AMCU decisions would serve as evidence in possible future private actions. Presented here is also a statistical analysis of existing compensation dynamics as an indicator of the popularity of antitrust damages actions in Ukraine. The fourth section shows the very limited efficiency of the existing antitrust damages compensation system and identifies new sources of such damages. The need to consider the latter is further on stressed both in the practice of antitrust damages actions and even in the wider context of competition protection. The paper ends in conclusions that finalize the analytical results presented.

\section{Legal rules on private enforcement of competition law in Ukraine}

Violations of competition rules, especially infringements as serious as cartels or abuses of monopoly powers, cause considerable damages not only to competition as a whole, but also to specific market participants. In Ukraine, most of the work to restore market competition is conducted by the Antimonopoly Committee of Ukraine (hereafter, AMCU) ${ }^{1}$.

Article 12 LPEC defines the conditions under which an undertaking is deemed to hold a dominant market position. An undertaking is understood to be dominant if its market share exceeds $35 \%$, unless it proves that it is in fact exposed to substantial competition. A market share equal to or less than $35 \%$

1 Official website of the Antimonopoly Committee of Ukraine, www.amc.gov.ua (accessed 16.03.2015). 
may be considered dominant if its holder does not face substantial competition, particularly due to relatively small market shares of its competitors ${ }^{2}$.

The results of public enforcement proceedings conducted by the AMCU have little impact on injured market players and consumers. Still, the importance of victims' satisfaction deriving from the fact that justice has been served and the offender punished should not be underestimated. The termination of an infringement is a natural and expected result but its effect is directed to the future. A question arises here therefore: how can a party that suffered losses from the misconduct of a particular market player find compensation for the negative consequences of acts committed in the past?

Damages actions are most widely used in the US and in the UK, but private law actions are now brought before the courts of many other countries also. Hence, attempts are made across the board to introduce appropriate legal standards.

Compensation for damages caused by an antitrust violation can be facilitated both in special legislation on private antitrust lawsuits (as is the case in the US and Germany) and in general civil law tort rules.

In Ukraine, filing a private law claim for an antitrust breach is a rare phenomenon, despite the fact that such suits are allowed by existing legislation. The legal basis for the filing of private suits lies in the norms of Article 224 of the Commercial Code of Ukraine which states that 'A participant of economic relations that violated the business obligation or the established requirements on the economic activities shall compensate the losses to the person, which rights or legitimate interests have been violated'. According to Article 55 LPEC, '[p]ersons who have suffered damage as a result of violation of legislation on protection of economic competition, may apply to the commercial court for a compensation'.

According to Article 55(2) LPEC, double compensation can be claimed for losses caused by an abuse of monopoly powers and by the participation in a concerted practice.

Actions for damages are governed by the basic principles on civil liability established in Chapter 24 of the Civil Code of Ukraine (hereafter, CCU). In order to establish the civil responsibility of a given individual, all elements of civil responsibility have to be established: the infringement of competition law, fault, damages, and a causal link.

Yet when it comes to private enforcement of competition law, certain deficiencies of Ukrainian law come to the surface, which hinder this enforcement model.

2 The Law of Ukraine on the Protection of Economic Competition, http://zakon2.rada.gov. ua/laws/show/2210-14 (accessed 16.03.2015). 
First, the CCU does not limit the range of individuals who may submit a civil action. As a result, damages can be claimed by members of a broad group of individuals including: competitors, customers, suppliers, and so on.

Article 45 of the Civil Procedural Code of Ukraine (hereafter, CPCU) specifies the general prerequisite for the protection of the interests of certain groups (particularly unspecified individuals). Accordingly, in cases established ex lege, a number of entities (the Commissioner of the Verkhovna Rada of Ukraine on human rights, public authorities, local governments, individuals as well as legal entities) may apply to the court for the protection of rights, freedoms and interests of others, as well as of national or public interests, and to take part in these proceedings. However, this provision lacks required scientific substantiation. It also lacks specific procedural mechanisms to protect subjective rights not of individual entities, but of a collective ${ }^{3}$.

Second, the main difficulty on the path to damages compensation in Ukraine is the issue of the burden of proof. The burden of proving an antitrust violation rests with the plaintiff, who must provide its evidentiary basis, develop a legal strategy of proof, provide documentation that confirms the appearance of losses, as well as to carry out their exact calculation. A final decision of the AMCU will act as proof of the infringement. It is fair to say that a claim for damages compensation, after the AMCU (or its authorized territorial body) recognizes a specific person has committed an antitrust violation, strengthens the legal position of the plaintiff, as the decision of the antitrust body confirms an infringement.

Having said that, national legislation makes it possible to also file civil claims independently from an AMCU decision. Since appeal proceedings to AMCU decisions may last for several months, the plaintiff will be forced to wait for the decision of the last instance court to have definite proof of an antitrust violation (final AMCU decision). If a plaintiff brought an action without waiting for the results of the appeal, should the court once again assess the circumstances of the antitrust breach? It is likely that in such cases the defendant will ask the court to suspend the damages proceedings pending the appeal ruling. The fact cannot be excluded also that the plaintiff may be required to get an expert opinion on some issues related to the case.

In practice, some of the documents containing the information required for a civil damages claim may be held by the defendant or by $3^{\text {rd }}$ parties. These might not be made available to the plaintiff upon its request. Ukrainian procedural law provides the court with the authority to call for evidence on the

3 A. Gubska, 'Group action and other representative actions: differentiating criteria' (2014) 3 Judicial bulletin, http://irbis-nbuv.gov.ua/cgi-bin/irbis_nbuv/cgiirbis_64.exe?C21COM=2\&I21 $\mathrm{DBN}=\mathrm{UJRN} \& \mathrm{P} 21 \mathrm{DBN}=\mathrm{UJRN} \& \mathrm{IMAGE}$ FILE_DOWNLOAD $=1 \&$ Image_file_name $=\mathrm{PDF} /$ Npnau_2014_4_17.pdf. (accessed 16.03.2015). 
basis of an application of the plaintiff. In such cases, the applicant must indicate what circumstances (relevant for the proper consideration and resolution of the case) may be confirmed or disproven by the requested evidence. The plaintiff must also state the reasons preventing it from obtaining the evidence as well as specify its location. This is clearly difficult, especially when it comes to compensation of damages caused to an end-user who is not familiar with the activities of the defendant.

For example, if a monopolist overstates the price of goods, an injured party would need to tell the court the specific amount overpaid. If the injured entity is not a procedural party in the AMCU case, it will not have access to the full text of the decision. In such cases, the plaintiff may apply to the court to request the disclosure of the AMCU decision as evidence. But even having received the full text of the antitrust decision, the plaintiff will not find in it a specific damages amount. The civil claimant will only find an indication of the fact that over-pricing has actually occurred.

Other barriers to effective private enforcement of competition law in Ukraine include:

- high legal costs and substantial uncertainty about the final outcome of such claims ${ }^{4}$;

- unawareness of potential claimants of their right to claim compensation, or their unwillingness to spoil their relations with offenders; even if the plaintiff is successful in its civil litigation, it might afterwards prove difficult to continue doing business with the offender; after the AMCU issues its decision to stop the violation and the court decides on damages, a monopolist will still have sufficient influence on the market, which it can use against the plaintiff, without actually infringing the law; in such cases, its customers are forced to make a decision: either to maintain good relations with the counterparty, or win a civil case and remain without the main supplier.

If further business conduct does not depend on the quality of the relationship between the injured entity and the offender, damages compensation is quite a justified step to take. Hence, not only the chance of winning the civil court case but also the level of dependence of the claimant on the offender should be assessed in every case.

This is why few court rulings have actually been delivered in Ukraine in this context in recent years. In all these cases, injured parties received compensation from companies holding a monopoly in public utility services markets.

${ }^{4}$ N. Hurzheeva, 'Vyvchennia mozhlyvostej rozbudovy instytutu hrupovoho pozovu v Ukraini' (2009) Zakhyst nevyznachenoho kola spozhyvachiv u sviti ta v Ukraini, http://www.consumerinfo. org.ua/upload/iblock/b62/ (accessed 18.03.2015). 


\section{Quantifying harm from antitrust infringements in Ukraine}

The quantification of harm caused by antitrust infringements is a major element of the antitrust damages actions system. Ukraine does not have a clear procedure for the estimation of such harm. Although there are no special legislative or other regulatory acts concerning this matter, some national practice exists (and its analysis is vital because, as noted above, AMCU decisions would be used as evidence in private actions) which is worth analysing in comparison with European standards.

The approaches used to quantifying harm caused by antitrust infringements depend on the type of violation in question. Dividing the latter into price and non-price antitrust infringements - the former manifest in overcharges, the latter are set aside from overcharges and are commonly referred to as 'exclusionary practices'. They include: predation, exclusive dealing, refusal to supply, tying, bundling and margin squeeze. This is a common classification used by researchers ${ }^{5}$ and experts ${ }^{6}$.

In the cases of price violations, Ukrainian officials quantify harm as a multiplication of the overcharge by the volume of the product sold under the infringement. This gives them a sum of additional customer expenses:

$$
H=\Delta P \times Q_{t}
$$

(formula 1)

where $H$ - harm caused by a price rise;

$\Delta P$ - overcharge;

$Q_{t}$ - product volume sold during the infringement period ${ }^{7}$.

In the cases of non-price infringements, the value of harm is quantified as a value of sunk costs, a loss of profit and so forth. However, some cases exist of non-price infringements where an overcharge analysis was used such

5 M.A. Han, M.P. Schinkel, J. Tuinstra, 'The Overcharge as a Measure for Antitrust Damages', Amsterdam Centre for Law \& Economics Working Paper No. 2008-08; http:// ec.europa.eu/competition/antitrust/actionsdamages/schinkel.pdf (accessed 11.03.2015); S. Salop, 'Exclusionary Conduct, Effect on Consumers, and the Flawed Profit-Sacrifice Standard' (2006) (73) Antitrust Law Journal 312; P. Buccirossi, 'Quantification of Damages in Exclusionary Practice Cases' (2010) 1(3) Journal of European Competition Law \& Practice 252-256.

${ }^{6}$ Practical Guide to Quantifying Harm in Actions for Damages Based on Breaches of Article 101 or 102 of the Treaty on the Functioning of the European Union, hereafter, the Practical Guide; paras. 15, 136 and 180.

${ }^{7}$ Formalized by the authors using an Instructive Letter on Quantifying of Economic Effect of Antitrust Violations Cease by Structural Bodies and Territorial Offices of Antimonopoly Committee of Ukraine No. 200-29/99-3379 (17.04.2014). 
as JCC Kyivguma vs JCC Kyivoblenergo. Kyivoblenergo (monopolistic owner of electricity transmission infrastructure in the Kyiv region) precluded an independent electricity supplier - The Central Power Company - from using electricity transmission infrastructure. The monopolist wanted to prevent consumers (Kyivguma was one of them) from buying electricity from The Central Power Company in favour of Kyivoblenergo, who also operated on the electricity supply market. However, the price of electricity charged by the competitor (The Central Power Company) was lower than that of the monopolist (Kyivoblenergo). Hence the consumer, Kyivguma, claimed compensation for its additional costs caused by the price difference. Its value was quantified by the abovementioned formula 1 - as a multiplication of the price difference by monthly volume of electricity consumption by Kyivguma (the infringement lasted only for once month and was stopped at the next monthly auction for electricity supply in the State Enterprise 'Energy market') ${ }^{8}$.

However, this case provided only partial compensation. Kyivguma (injured 'consumer') has gotten the compensation, but The Central Power Company (injured 'competitor') has not. The latter did not even try to get compensation through the courts, notwithstanding the significant value of its lost profit. The reason for such behaviour could be found in the complexity of quantifying and grounding as well as getting a court confirmation of the value of lost profit. There are not precedents of such type in Ukraine, while compensations in cases of antitrust price violation are common. They will be the focus of the following analysis.

The methodology of quantifying the value of an anticompetitive overcharge in Ukraine is similar to the European approach ${ }^{9}$. It involves comparing the actual performance of the company (especially prices) with performance which would have existed in the absence of the infringement (non-infringement scenario). So, the key challenge in assessing the value of harm from antitrust infringements is the formulation of a non-infringement scenario. Two groups of methods are used in this context: comparison-based methods and simulation methods (Figure 1).

All of these methods are used in Ukraine besides theoretical modelling.

The method of 'comparing data from other geographic market' is used in Ukrainian antitrust practice when the infringement is committed on a regional market that is close or even identical to a number of adjacent geographic markets. An example here is provided by the cartel case that occurred on

\footnotetext{
8 Annual Report of Antimonopoly Committee of Ukraine 2008, p. 82-84.

9 See Directive 2014/104/EU of the European Parliament and of the Council of 26 November 2014 on certain rules governing actions for damages under national law for infringements of the competition law provisions of the Member States and of the European Union (OJ L 349, 05.12.2014, p. 1), hereafter, the Damages Directive, Art. 2(20).
} 
Figure 1. Methods of constructing a non-infringement scenario

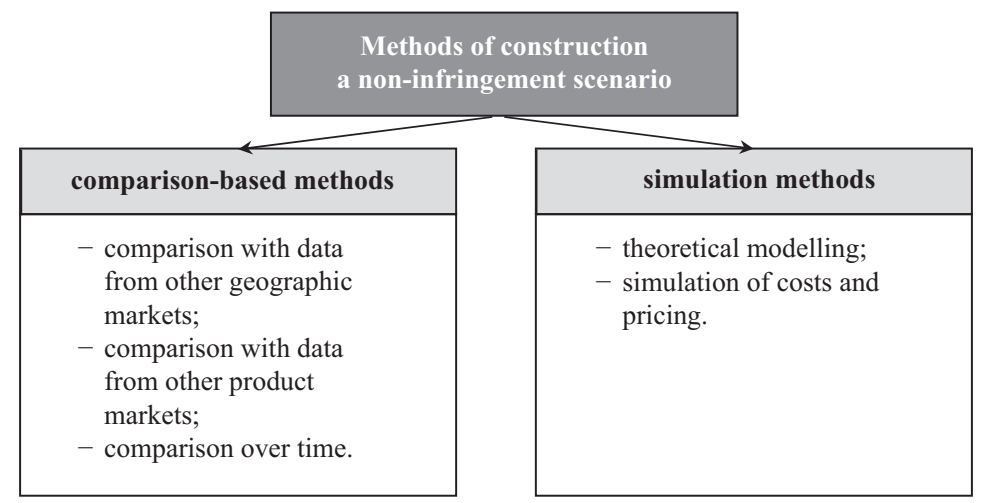

Source: created by the author using the content of the Practical Guide, paras 38-39 and 96.

the milk procurement market in some districts of the Ivano-Frankivsk region. The actual procurement prices were understated by a factor of 1.4-1.67 by four dairy plants (Kolomyisky syrzavod, Snyatynsky syrzavod, Gorodenkivsky syrzavod and Maslozavod (Tlumach town)), which together occupy a dominant position on the relevant market. The Ivano-Frankivsk Territorial Office of AMCU compared these plants' prices with the prices on the milk procurement markets in other districts of the Ivano-Frankivsk region. The authorities found that their prices were $25 \%-40 \%$ lower than comparable rates in other districts. The plants involved were obliged to compensate the incurred losses to injured households. The value of the losses was quantified as a difference between the average region price of milk procurement and the price paid to households under the infringement, multiplied by the volume of milk procured under the infringement ${ }^{10}$. So, this example also meets the requirements of the quantifying approach formalized in formula 1.

The method of 'comparing data from other product market' compares the price of the investigated good with prices of it substitutes. Among the examples of the use of this method in Ukrainian antitrust practice is the case of wireless engineering procurement by the Ukrainian state operator of rail transport Ukrzaliznitsya. Suppliers of wireless engineering (Arcom and CTI) engaged in tender fixing. As a result of their anticompetitive practice, the price under the tender became higher than on the open market. Here, the comparison covered markets were the same product was sold to different groups of customers: state rail transport operator versus private customers. The difference between the tender price and the price of the same wireless engineering on the open market formed the first part of formula 1. The second part was determined

10 Annual Report of Antimonopoly Committee of Ukraine 2002, p. 35. 
as the volume of the tender procurement. The value of the damages granted to Ukrzaliznitsya amounted to UAH 400000 (EUR 58 000) ${ }^{11}$.

The next method of constructing a non-infringement scenario is rather complex and focuses on a 'comparison over time'. It is rarely used in Ukraine since the national economy is dynamic, and it is difficult to compare prices set in different chronological periods. This method can be used for short-term infringements where it is possible to compare prices charged during the infringement period and those in an unaffected post-infringement period (comparison 'during and after'). This method was used in the wood cartel case ${ }^{12}$. However, such cases are sporadic and they rarely involve damages actions. The possibility of adequate price comparison over time is limited by long infringement periods and the dynamic nature of the Ukrainian business environment, which does not facilitate the detection of the anticompetitive component of the price change.

Unlike 'comparison-based' methods of constructing a non-infringement scenario, 'simulation methods' (simulation of costs and pricing) involve the analysis of the cost structure. Simulations are usually used in cases of antitrust violations on regulated markets, especially natural monopoly markets.

There are rich experiences of damages compensation with regard to consumers on such markets in Ukraine. Listed among the reasons for such compensation can be:

- providing poor quality services (for example, non-ambient temperature conditions during the heating season);

- providing services at pre-arranged (predictive) prices, irrespective of the real costs of energy consumption (for example, refusal to revaluate the tariff $^{13}$ when the actual average winter temperature is higher than the predicted one);

- duplication of certain components' value in the cost and ultimately in the tariff (for example, the costs for meter calibration) etc.

These actions result in an overstating of the costs and price of the service. Formula 1 can be used for its analysis but by replacing $\Delta P$ for $\Delta C$.

$$
H=\Delta C \times Q_{t}
$$

(formula 2)

where $\Delta C$ - unjustified increase in costs that compound the regulated tariff.

11 Annual Report of Antimonopoly Committee of Ukraine 2009, p. 35.

12 In this case, the Association 'Mebliderevprom' coordinated the anticompetitive concerted actions on the wood market which led to the overcharge. The infringement lasted for a year (2011) and was stopped by AMCO. After that the price of wood decreased almost to the preinfringement level; Annual Report of AMCO 2012, available at: http://www.amc.gov.ua/amku/ doccatalog/document?id=95114\&schema $=$ main $($ accessed 16.03.2015).

13 Many Ukrainian consumers have no special gauges for the use of heating and use the tariff set for a square meter of living space. 
In the first half of the 2000s, about one third of the overall value of compensations related to such infringements. This figure is now significantly lower, as well as the value of compensation that is kept count by AMCU (Figure 2). This shift is caused by a number of interrelated factors.

Figure 2. Dynamics of the value of private compensations of harm from antitrust infringements (data from AMCU)

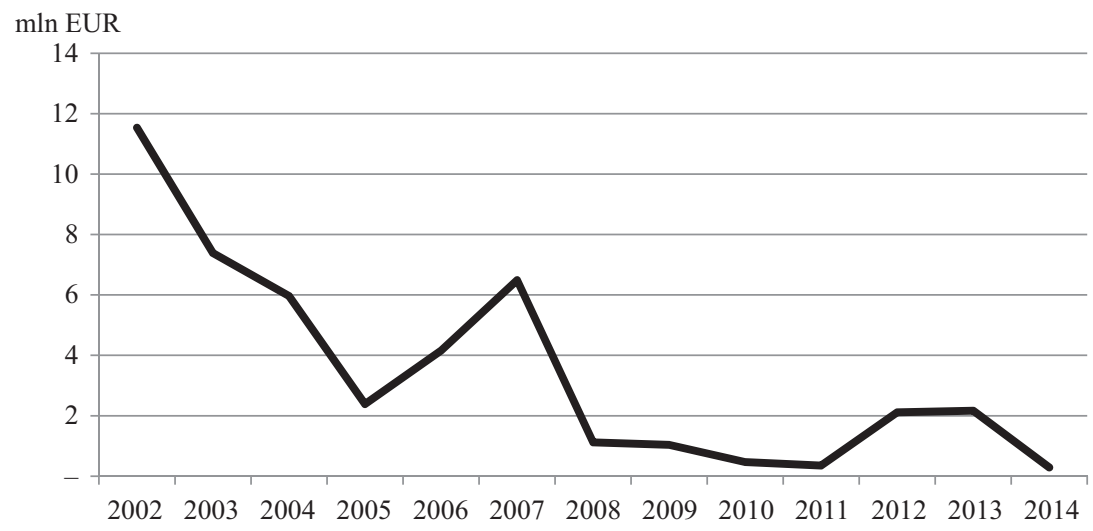

Source: Annual Reports of AMCU 2002-2014.

The first reason for the shift lies in that the consumer circle of natural monopolists consists of thousands of households. The bargaining power of each individual household is far too weak to establish favourable terms of service consumption. Simultaneously, the value of the harm suffered by an individual household from the abuse by a natural monopolist is negligible in comparison to the cost of counteracting the monopolist. Moreover, the ability of individual households to unite to counter natural monopolists (also in cases of damages compensation) remains weak. According to the StiglerPeltzman model, the market (with a court system acting as an instrument of guaranteeing its effectiveness) cannot cope with the problem of damages compensation to dispersed households ${ }^{14}$. This must be done by government agencies, primarily by the AMCU. So such compensation will only be adequate if the problem is kept in check by the AMCU. But this solution is not provided by Ukrainian Law, which brings this issue entirely into the sphere of civil law.

The second reason for the shift is the change in the mission of the AMCU. At the beginning of 2000s, independent regulators did not exist in most areas

14 S. Peltzman, 'Toward a More General Theory of Regulation' (1976) 19 Journal of Law and Economics 211-240. 
of natural monopolies. The AMCU had to act in their regulatory capacity, which included price regulation in the sphere of utilities. Today such regulators exist and the activity of the AMCU centres on the development of competition and counteracting monopolization of potentially competitive markets. This area does not cover the above discussed class of infringements (as well as the relevant procedures of damages compensation). Today, such practices are out of the control of the AMCU.

The latter explains the rapid downward trend of private compensations value shown in Figure 2. But this dynamics does not show the overall trend in damages compensations in Ukraine - it is only a narrow AMCU statistics that ignores another sphere of damages compensations in the country.

Starting with the structure of total recovery ${ }^{15}$ in $2002-2007^{16}$ and the data on infringements committed and fines paid in 2002-2014, it is possible to estimate the change in value of private damages compensations in the following years of 2008-2014 (Figure 3).

Figure 3. Dynamics of estimated value of compensated harm in Ukraine (if the structure of total recovery stays fixed)

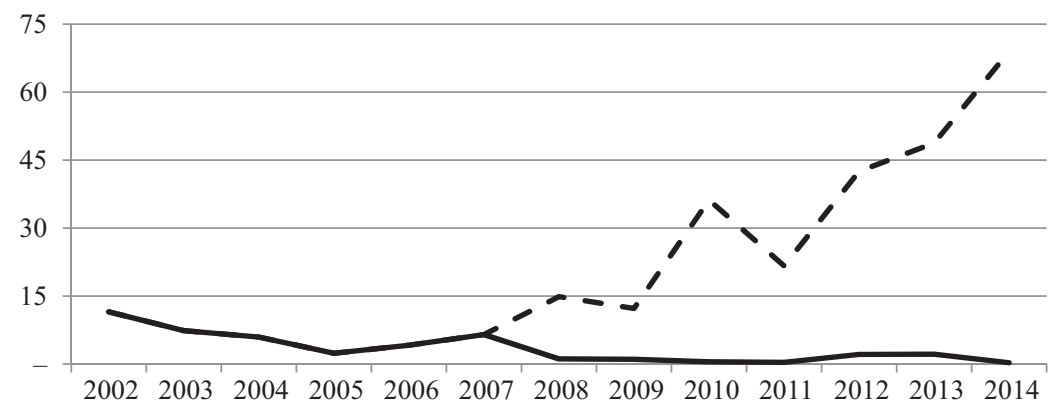

Source: Created by the author using data provided in Annual Reports of AMCU 2002-2014.

Figure 3 shows that the estimated value of 'compensated' harm (in other words, value of compensation actually paid) in antitrust cases can almost reach the point of 70 million EUR in 2014 - by contrast to the officially stated amount of 300000 EUR.

It should be noted that the rapid increase in the estimated value of compensated harm in recent years should not be considered evidence of lack

15 Total recovery is the total value of funds that was returned by the antitrust infringers to the society (State, competitors, suppliers, consumers). It consists of fines and compensated harm.

16 The period of 2002-2007 was characterised by the strict control exercised by AMCU over the process of compensation of damages caused by antitrust violations. So AMCU data for that period is relatively complete. 
of accuracy of the proposed assessment methodology. On the contrary, it correlates far better, than the official statistics, with the calculated value of the economic effect of stopping antitrust infringements (individuals' and entities' costs savings on goods, budget savings or prevention of an increase in such costs, which are the result of stopping antitrust infringements by AMCU ${ }^{17}$ ). It is close to the value of damages ${ }^{18}$ and the relation between its doubled value and the value of compensated harm gives a rough measure of antitrust damages compensation in Ukraine (Table 1).

Table 1. Dynamics of the index of antitrust damages compensation in Ukraine

\begin{tabular}{|c|c|c|c|}
\hline Year & $\begin{array}{c}\text { Economic effect of stopping } \\
\text { antitrust infringements, } \\
\text { million euro }\end{array}$ & $\begin{array}{c}\text { Corrected value of } \\
\text { compensated harm, } \\
\text { million euro }\end{array}$ & Index of compensation \\
\hline$[1]$ & {$[2]$} & {$[3]$} & {$[4]=[3] /([2] \times 2) \times 100 \%$} \\
\hline 2002 & 10.24 & 11.54 & 56.33 \\
\hline 2003 & 10.29 & 7.38 & 35.87 \\
\hline 2004 & 15.89 & 5.96 & 18.77 \\
\hline 2005 & 38.37 & 2.38 & 3.11 \\
\hline 2006 & 16.38 & 4.16 & 12.69 \\
\hline 2007 & 6.09 & 6.49 & 53.29 \\
\hline 2008 & 3.89 & 14.88 & 191.48 \\
\hline 2009 & 13.70 & 12.26 & 44.79 \\
\hline 2010 & 11.13 & 36.19 & 162.62 \\
\hline 2011 & 44.11 & 21.66 & 24.55 \\
\hline 2012 & 131.47 & 42.53 & 16.18 \\
\hline 2013 & 292.12 & 48.78 & 8.35 \\
\hline 2014 & 47.88 & 69.00 & 22.07 \\
\hline Total & 641.54 & 283.21 & 206 \\
\hline
\end{tabular}

Source: Created by the author using data from Annual Reports of AMCU 2002-2014.

${ }^{17}$ Instructive Letter on Quantifying of Economic Effect of Antitrust Violations Cease by Structural Bodies and Territorial Offices of Antimonopoly Committee of Ukraine No. 20029/99-3379 (17.04.2014), p. 2.1.

${ }^{18}$ The value of damages includes the value of the real harm experienced from the exploitation of market power, while the compensated damages can be doubled. Art. 55 LPECc N 2210-III at 11.01.2001, [in:] V. Tsusko, M. Barash, M. Fedosiyenko, T. Kulishova, V. Talakh, N. Arnaut (eds.), Compendium of Legislation of Ukraine on Protection of Economic Competition In 2 Vol., vol. 1, p. 124; http://www.amc.gov.ua/amku/doccatalog/document?id=94745\&schema=main (accessed 16.03.2015). 
The Index of compensation is not a stable figure because an infringement can be stopped in the first period, while compensation might be paid in the second period. For the whole investigated period (2002-2014), this index is about $22 \%$. This is evidence of powerful reserves for the development of antitrust damages actions in Ukraine.

\section{New sources of damages caused by market power}

According to part 3 (para 128) of the Practical Guide, the value of harm caused by antitrust violations is represented by the area of the trapeze $P_{m} M C P_{c}$ on Figure 4.

Figure 4. Harm caused by antitrust infringements

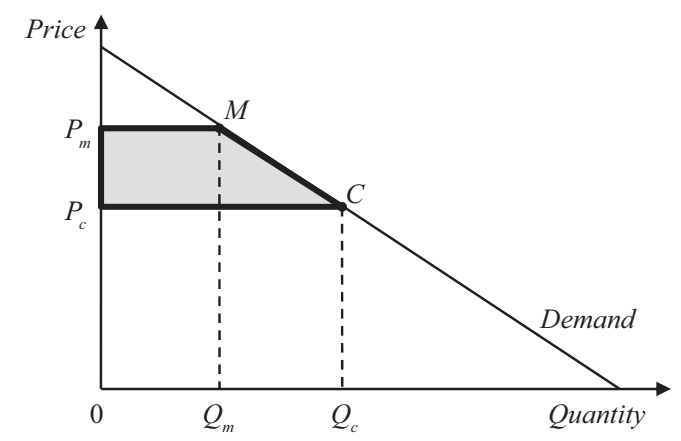

Source: Practical Guide, para 128.

According to the approach of R. Posner, which is considered to be fundamental in the measurement of the value of welfare loss in modern economics, the welfare loss from market power has the same schematic dimension ${ }^{19}$. Unlike harm caused by antitrust infringements, and the economic effect of stopping antitrust infringements, which are both calculated on the given market where the infringement occurred, welfare loss measures the harm suffered from market power by the entire economy, including implicit economic losses such as ineffective use of economic resources and exploitation of market power.

After investigating the value of welfare loss for the Ukrainian economy in 2008-2011, it emerges that its average yearly value (calculated with R. Posner's

19 R. Posner, 'The Social Cost of Monopoly' (1974) 55 NBER working papers, p. 2-3. 
methodology) amounts to UAH 373.2 billion (about Euro 33 billion) ${ }^{20}$. Comparing it with the value of compensated damages, it is evident how truly insignificant the latter is - compensated harm amounts to less than $0.1 \%$ of total welfare loss. Large value of welfare loss and the poor practice of damages compensation can be seen in other national economies also ${ }^{21}$.

The result of this comparison is the reason for looking for the causes and ways of overcoming the disjuncture between 'compensated' damages and welfare loss. It is not enough to merely improve the procedures for damages compensation in antitrust cases. It is necessary to realise the existence of implicit sources of welfare loss in day-to-day business, which are caused by:

a) lack of effectiveness of antitrust regulation (each undetected/persisting abuse contributes to the gap, reducing the effectiveness of certain industry sectors as well as of the entire economy);

b) existence of a range of legal business practices that help create, strengthen and protect the market power of private entities, and let them exploit it effectively.

Researchers and those engaged in the implementation of state competition policy are aware of the first group of the sources of welfare loss - they are a matter of continued legal improvement. For example, Ukrainian antitrust law can deal with some of them by adopting certain provisions of EU law. As for the second group, those factors remain implicit not only in Ukraine, but even in developed countries with deeply rooted traditions of competition protection. Focusing therefore on the second group of the sources of welfare loss, three questions should be answered. What business practices can cause welfare loss? How can they raise welfare loss? How to calculate the resulting damage?

Industrial economics and modern antitrust practice, the latter built on the achievements of the former, have investigated in detail the effects of market power onto market supply. They are the basis for national laws and other regulatory documents in the field of competition. At the same time, the effects of market power onto demand are only studied in theory, the latter explaining them as the result of some business practices that are able to distort a demand function of a consumer. These include:

20 A.G. Gerasymenko, Market power: sources, scope, consequences, Kyiv National University of Trade and Economics Press, Kyiv 2014, p. 317.

21 F.M. Fisher, 'Economic Analysis and Antitrust Damages' (2006) 29(3) World Competition 383-394; A. Daskin, 'Deadweight Loss in Oligopoly: A New Approach' (1991) 58(1) Southern Economic Journal 171-185; S.B. Avdasheva, N.M. Rosanova, The Theory of Industrial Markets Organization, Magistr, Moscow 1998, p. 88. 
excessive product differentiation (H. Hotelling ${ }^{22}$, S. Salop ${ }^{23}$, K. Lancaster ${ }^{24}$ ), asymmetric information (G. Akerlof ${ }^{25}$, J. Stiglitz ${ }^{26}$ ), persuasive advertising (R. Schmalensee ${ }^{27}$, P. Milgrom ${ }^{28}$ ) and other business practices, as well as a mix of the above. But the problem is that it is in practice quite difficult to separate such manifestations of the exploitation of market power from the normal course of business conduct.

Business conduct of forming a market power zone in a product space, and its strengthening by persuasive advertising, uses excessive product differentiation (also by way of persuasive advertising) to place the item in as far away the product space from others substitutes as possible. The Salop Model of Circular City grounds the potential of such a practice, which makes the consumer of a product pay more for the opportunity to enjoy its benefits ${ }^{29}$. This behaviour is not a priori harmful. It is not prohibited. It raises harm only (a) when the overcharge is not provided by real differences in product quality and, (b) when it brings a profit margin much higher than the normal rate.

Ordinary instruments of quantifying harm cannot be used here because such overcharge is not caused by a monopolistic decrease of output. A different method of damage estimation is needed based on the difference between the declared and actual utility of the good, rather than solely on the price difference.

The proliferation of trademarks and proactive product innovations are able to preserve market structures and facilitate individual and collective dominance, similar to any other barriers to potential competition. However, unlike predatory pricing or sunk costs, methods to distinguishing between fair and unfair practices do not exist when it comes to the updating of a product range. There are no clear indicators of the ability of demand manipulation practices to raise market power and the associated welfare loss.

${ }^{22}$ H. Hotelling, 'Stability in Competition'(1929) 39 The Economic Journal 41-57.

23 S. Salop, 'Monopolistic Competition with Outside Goods' (1979) 10 Bell Journal of Economics 141-156.

${ }^{24}$ K. Lancaster, 'The Economics of Product Variety: a Survey' (1990) 9(3) Marketing Science 189-206.

25 G.A. Akerlof, 'The Market for 'Lemons': Qualitative Uncertainty and the Market Mechanism' (1970) 84(3) The Quarterly Journal of Economics 488-500.

26 J.E. Stiglitz, 'Equilibrium in Product Market with Imperfect Information' (1979) 69(2) The American Economic Review 339-345 (Papers and Proceedings of the 91 Annual Meeting of the American Economic Association).

27 R. Schmalensee, Advertising and Market Structure, Forgotten Books, Charleston 2012.

28 P. Milgrom, 'What the Seller Won't Tell You: Persuasion and Disclosure in Markets' (2008) 2(2) Journal of Economic Perspectives 115-121.

29 S. Salop, 'Monopolistic Competition with Outside Goods' (1979) 10 Bell Journal of Economics 141-156. 
As for the approaches to the estimation of the harm suffered from such conduct of a market power holder, they can be similar to those that are used in the EU in foreclosure cases. They refer to three kinds of losses: actual loss suffered (damnum emergens), compensation for the profit a potential competitor had lost due to an infringement (lucrum cessans), and the payment of interest ${ }^{30}$. Actual losses must be calculated as a value of additional costs of overcoming the barrier notwithstanding the result (whether there was a potential competitor entering the market or not), reflecting the so-cold Stigler approach to the definition of barriers ${ }^{31}$. The second and the third type of loss must be calculated as a value of lost profit of potential competitors, who refuse to enter the market.

It is clear that these two examples do not exhaust the entire range of anticompetitive practices of demand manipulation that can harm individuals (both persons and companies) and the society as a whole. However, they define a vector for further studies in the sphere of antitrust damages actions and the development of competition at large.

\section{Conclusion}

Public enforcement of competition law still plays a dominant role in Ukraine. In order to ensure that private antitrust lawsuits successfully operate in Ukraine, without rights abuses from both sides, the following measures are proposed:

- to develop a mechanism for access to evidence held by the defendant;

- to adopt legislative norms defining who can initiate actions for damages caused by antitrust violations (direct or indirect customers);

- to provide the possibility for collective actions by groups of plaintiffs.

The approaches to quantifying the value of damages are similar in Ukraine and the EU. Most differences are sectorial. For example, the largest share of damages compensations in the Ukraine (mostly in early 2000s, but also today) concerns natural monopolies. Detecting abuses on such markets entails not only the punishment of the offender, but also compensation for damages incurred by its customers. This can be public or private in nature. The Decision of the AMCU, which established an abuse, can be used as evidence of a violation by the injured entity. The active role of AMCU in such cases removes one of the thorniest problems of the damages compensation procedure - quantifying the value of the harm caused by the antitrust infringement.

30 Damages Directive, Art. 3, para. 2; Practical Guide, para. 183.

31 G.J. Stigler, The Organization of Industry, Richard D. Irwin, Homewood 1968. 
The abovementioned involvement of the AMCU would thus be considered 'indirect' antitrust damages enforcement because the AMCU is a public body. Its active involvement in the process of damages compensation changes the classical disposition of the parties, being the driving force of the whole process's transformation from private enforcement into the public one. Direct private antitrust enforcement works in Ukraine only in cases of a 'big company vs. a monopolist (or cartel)' and only with respect to overcharging. This is so, first, because small companies are too weak to bear the burden of court actions in Ukraine's corrupted economy. The second cause lies in poor competitive education of average Ukrainians. Neither Ukrainian entrepreneurs, nor lawyers have enough skills to ground the actual value of profit loss as a result of monopoly abuse (or a cartel). Only AMCU staff can really do it.

There is an urgent need for competition advocacy in the sphere of antitrust damages actions. This would intensify the practice of antitrust damages actions as a 'yesterday step' and make Ukrainian society ready for the challenges of today or even tomorrow, such as the abovementioned practices of demand manipulation.

\section{Literature}

Akerlof G.A., 'The Market for 'Lemons': Qualitative Uncertainty and the Market Mechanism' (1970) 84(3) The Quarterly Journal of Economics.

Avdasheva S.B., Rosanova N.M., The Theory of Industrial Markets Organization, Magistr, Moscow 1998.

Buccirossi P., 'Quantification of Damages in Exclusionary Practice Cases' (2010) 1(3) Journal of European Competition Law \& Practice.

Daskin A., 'Deadweight Loss in Oligopoly: A New Approach' (1991) 58(1) Southern Economic Journal.

Fisher F.M., 'Economic Analysis and Antitrust Damages' (2006) 29(3) World Competition. Gerasymenko A.G., Market power: sources, scope, consequences, Kyiv National University of Trade and Economics Press, Kyiv 2014.

Gubska A., 'Group action and other representative actions: differentiating criteria' (2014) 3 Judicial bulletin, http://irbis-nbuv.gov.ua/cgi-bin/irbis_nbuv/cgiirbis_64.exe?C21COM $=2 \& I 21 D B N=U J R N \& P 21 D B N=U J R N \& I M A G E \_F I L E \_D O W N L O A D=1 \& I m a g e$ file_name $=$ PDF/Npnau_2014_4_17.pdf

Han M.A., Schinkel M.P., Tuinstra J., 'The Overcharge as a Measure for Antitrust Damages', Amsterdam Centre for Law \& Economics Working Paper No. 2008-08; http://ec.europa.eu/competition/antitrust/actionsdamages/schinkel.pdf

Hotelling H., 'Stability in Competition'(1929) 39 The Economic Journal.

Hurzheeva N., 'Vyvchennia mozhlyvostej rozbudovy instytutu hrupovoho pozovu v Ukraini' (2009) Zakhyst nevyznachenoho kola spozhyvachiv u sviti ta v Ukraini http://www. consumerinfo.org.ua/upload/iblock/b62/ 
Lancaster K., 'The Economics of Product Variety: a Survey' (1990) 9(3) Marketing Science. Milgrom P., 'What the Seller Won't Tell You: Persuasion and Disclosure in Markets' (2008) 2(2) Journal of Economic Perspectives.

Peltzman S., 'Toward a More General Theory of Regulation' (1976) 19 Journal of Law and Economics.

Posner R., 'The Social Cost of Monopoly' (1974) 55 NBER working papers.

Salop S., 'Exclusionary Conduct, Effect on Consumers, and the Flawed Profit-Sacrifice Standard' (2006) (73) Antitrust Law Journal.

Salop S., 'Monopolistic Competition with Outside Goods' (1979) 10 Bell Journal of Economics.

Schmalensee R., Advertising and Market Structure, Forgotten Books, Charleston 2012.

Stiglitz J.E., 'Equilibrium in Product Market with Imperfect Information' (1979) 69(2) The American Economic Review (Papers and Proceedings of the 91 Annual Meeting of the American Economic Association).

Stigler G.J., The Organization of Industry, Richard D. Irwin, Homewood 1968.

Tsusko V., Barash M., Fedosiyenko M., Kulishova T., Talakh V., Arnaut N. (eds.), Compendium of Legislation of Ukraine on Protection of Economic Competition In 2 Vol., vol. 1; http://www.amc.gov.ua/amku/doccatalog/document?id=94745\&schema=main. 